Marta Materska-Samek (D) https://orcid.org/0000-0002-4432-0933

Uniwersytet Jagielloński

Otrzymano/Received: 5.01.2020

Zaakceptowano/Accepted: 22.02.2020

Opublikowano/Published: 31.03.2020

\title{
Kultura naszym biznesem? 0 niedocenionym mechanizmie finansowania rozwoju kultury w ramach dzialalności badawczo-rozwojowej polskich przedsiębiorstw
}

\footnotetext{
$\mid$
}

\begin{abstract}
Culture is Our Business? Underestimated Financing Schemes for Development of Culture as Part of the Research and Development Activities of Polish Enterprises
\end{abstract}

This article deals with issues of cultural management, and in particular the acquisition of financial resources from European Union funds. It analyzes the possibilities of financing the development of culture with funds allocated to innovation, research and development. Its purpose is to diagnose the barriers encountered by Polish enterprises conducting research and development activity in the area of KIS 13 "Intelligent creative technologies" when designing and obtaining funding. The article is based on evaluation studies of national and regional intelligent specializations, materials related to the assessment procedure and evaluation of projects, observations of the author assessing projects submitted for co-financing, and thus new scientific sources.

Keywords: culture financing, R\&D activities, intelligent specializations, intelligent creation technologies

Słowa kluczowe: finansowanie kultury, działalność $\mathrm{B}+\mathrm{R}$, inteligentne specjalizacje, inteligentne technologie kreacyjne 


\section{Wprowadzenie}

Niezwykle rzadko rozwój kultury przewyższa na liście priorytetów politycznych cele związane z gospodarką czy wzmocnieniem jakości życia. Tworzenie prawa oraz programowanie (w tym finansowanie zadań w ramach programów) stanowią podstawowe narzędzia realizacji polityk publicznych. Zatem zgodność z celami wyznaczonymi przez te polityki i spełnienie warunków określonych przez programy wyznacza podstawę możliwości finansowania przedsięwzięć ze źródeł publicznych.

By skorzystać w obfitości środków europejskich zakontraktowanych dla Polski w latach 2007-2013, menadżerowie kultury nauczyli się przekonywać grantodawców do inwestycji w kulturę jako narzędzia budowania kapitału społecznego i czynnika znacząco wpływającego na jakość życia oraz przewagę konkurencyjną miast i regionów. Powołując się na argumentację o wpływie kultury na rozwój społeczny i gospodarczy [Smoleń 2003; Landry 2008; Florida 2010; Ilczuk 2012], $\mathrm{z}$ sukcesem przeprowadzono wiele rewitalizacji miast w Polsce [Prusik et al. 2015], modernizowano i cyfryzowano instytucje kultury [Materska-Samek, 2008, 2010] czy wzmacniano kompetencje kulturowe [Ilczuk, Krzysztofek 2011].

W kolejnym okresie programowania (2014-2020), w związku z chęcią wzmocnienia pozycji Europy jako światowego konkurenta i przywrócenia jej gospodarki na ścieżkę wzrostu po niedawnym kryzysie finansowym, badania i innowacje stały się centralnymi punktami Strategii na rzecz inteligentnego i zrównoważonego rozwoju sprzyjającego włączeniu społecznemu Europa 2020. Zwiększono zatem finansowanie programów wzmacniających badania i rozwój, w tym Horyzont 2020, a B+R stały się jednym z zasadniczych elementów inwestycji UE w programach krajowych korzystających ze środków na politykę spójności.

Działalność badawczo-rozwojową firm wyróżnia zwiększenie zasobów wiedzy oraz wykorzystanie tych zasobów do tworzenia nowych zastosowań. Ponadto jest to działalność obarczona wysokim ryzykiem niepowodzenia oraz wymaga zwiększonych nakładów. Biorąc pod uwagę, że wśród ważniejszych czynników determinujących tempo i poziom rozwoju gospodarczego znajdują się innowacyjność, transfer i wykorzystanie wiedzy, działalność $B+R$ bezpośrednio przekłada się na dynamikę innowacyjnej gospodarki, generowanie podaży nowych rozwiązań produktowych, procesowych, organizacyjnych [OECD 2018: 20].

Unia Europejska w tym okresie programowania inwestuje w innowacje 123 mld euro (35\% środków na politykę spójności), jednak pozyskanie tych środków wymagało od krajów członkowskich przygotowania krajowej i regionalnej strategii inteligentnej specjalizacji. To warunek wstępny (krytyczny czynnik, niezbędny do osiągnięcia wyznaczonego celu) pozyskania finansowania ze środków Europejskiego Funduszu Rozwoju Regionalnego (EFRR) przewidzianych na realizację celu tematycznego nr 1 (wzmacnianie badań naukowych, rozwoju technologicznego i innowacji), który ma także związek z celem tematycznym nr 2 (zwiększenie dostępności, 
stopnia wykorzystania i jakości Technologii Informacyjno-Komunikacyjnych) [Rozporządzenie Parlamentu Europejskiego i Rady (UE)... 2013]. Pojawił się tym samym warunek, który ograniczył pulę beneficjentów i wykluczył z możliwości ubiegania się o dofinansowanie sektory gospodarki niewykazane w krajowych czy regionalnych inteligentnych specjalizacjach.

Narodowe i regionalne strategie badań i innowacji na rzecz inteligentnej specjalizacji (RIS3) to zintegrowane, lokalnie definiowane programy transformacji gospodarczej, które:

- koncentrują się na kluczowych wyzwaniach i potrzebach w zakresie rozwoju opartego na wiedzy;

- wykorzystują mocne strony, potencjał i przewagę konkurencyjną danego kraju/regionu;

- sprzyjają innowacjom technologicznym i praktycznym, stymulują inwestycje sektora prywatnego;

- angażują interesariuszy, zachęcają do innowacyjności i eksperymentowania;

- opierają się na obiektywnych danych i dowodach [Foray et al. 2012].

W Polsce od 1 stycznia 2020 roku jest 14 krajowych inteligentnych specjalizacji, a w poszczególnych regionach ich liczba waha się od trzech do kilkunastu [Nazarko 2014: 255-256].

Niniejszy tekst ma na celu analizę możliwości finansowania rozwoju kultury ze środków przeznaczonych na innowacje i wsparcie prac badawczo-rozwojowych oraz wskazanie barier, jakie napotykają polskie przedsiębiorstwa prowadzące działalność badawczo-rozwojową w obszarze KIS 13 „Inteligentne technologie kreacyjne" przy projektowaniu i pozyskiwaniu dofinansowania. Tym samym odpowiem na pytania badawcze, czy obecny system premiuje działalność badawczą w kulturze objętą KIS 13 i sprzyja innowacjom oraz w jakim stopniu stanowi istotną barierę dla organizacji, które samodzielnie nie potrafią aplikować o środki i skorzystać ze wsparcia. Artykuł ma istotne znaczenie w naukach o zarządzaniu, gdyż wskazuje dylematy pozyskiwania bardzo cennych dla organizacji zasobów, z którymi muszą się mierzyć menadżerowie. Opisane w tekście zadania badawcze przeprowadzono metodami: analizy i krytyki piśmiennictwa, analizy dokumentów (raporty ewaluacyjne RIS, KIS czy PO IR, materiały dotyczące aplikowania o wsparcie, dokumenty strategiczne krajowe i europejskie), studium przypadku aplikującej organizacji oraz analizy i konstrukcji logicznej. Bardzo istotne okazały się materiały zebrane w wyniku wywiadów z przedsiębiorcami województwa małopolskiego na potrzeby ewaluacji RIS i zawarte w raporcie Jakościowe badanie małopolskich przedsiębiorstw działajacych w obrębie dziedzin wytyczonych przez inteligentna specjalizację regionu [2016]. W wywiadach dotyczących RIS „Przemysły kreatywne i czasu wolnego” wzięło udział siedmiu przedstawicieli firm dobranych na podstawie profilu działalności oraz deklarujących prowadzenie działalności wpisującej się w cztery dziedziny RIS-u na terenie województwa, dlatego badanie nie miało charakteru reprezentatywnego 
dla całego kraju. Jednocześnie, by dopełnić obraz ograniczeń, wykorzystano kolaż i dane pochodzące z nowszego, bo opublikowanego w 2018 roku, ogólnopolskiego raportu Ocena wsparcia udzielonego w ramach działania 1.2 PO IR na rozwój wybranych sektorów gospodarki.

Artykuł wykorzystuje także metodę autoetnografii, gdyż oparty jest na obserwacjach autorki zasiadającej w gremiach eksperckich oceniających przedłożone do dofinansowania projekty.

\section{Znaczenie kultury dla rozwoju gospodarki}

Zagadnienia odnoszące się do mechanizmów finansowania rozwoju kultury ze środków na działalność badawczo-rozwojową łączą w sobie dorobek naukowy dotyczący finansowania sektora kultury oraz kwestie specjalizacji gospodarki i wspierania działalności B+R. Finansowanie sektora kultury w Polsce opiera się na modelu, gdzie sektor publiczny jest dominującym, ale nie jedynym źródłem finansowania [Ilczuk 2012; Kopeć 2014; GUS 2016]. W wielu opracowaniach „kultura” jako przedmiot finansowania jest często utożsamiana ze zinstytucjonalizowaną sferą publiczną lub działalnością organizacji pozarządowych, a rola podmiotów prywatnych (przedsiębiorstw) omawiana jest najczęściej w kontekście realizacji polityk CSR i wpierania kultury ze źródeł prywatnych [GUS 2016]. Jednak typologia instytucjonalna sektora kultury obejmuje także organizacje prywatne [Knaś 2012], których produkcja jest objęta ochroną przez prawo autorskie a dostarczane kreatywne produkty stanowią element kultury symbolicznej. Zbiór tych organizacji nazywany jest przemysłami kultury i kreatywnymi (creative industries, CCI). Znaczenie gospodarcze kultury, a w szczególności przemysłów kreatywnych, od upowszechnienia tego terminu na początku XXI wieku jest szeroko omawiane w literaturze [KEA 2006; Thorsby 2010; Ulatowska et al. red. 2012]. W badaniach nad przemysłami kultury i kreatywnymi (CCI) analizowany jest wkład w tworzenie PKB [Kasprzak 2017], wpływ na rozwój przedsiębiorczości czy rozwój rynku pracy [Znaczenie gospodarcze sektora kultury... 2017], a także kreatywność i innowacyjność miast [Landry 2008; Florida 2010; Pięta-Kanurska 2013].

Bardzo ważnym elementem specyfiki przemysłów kultury jest ich innowacyjny charakter oparty na kreatywności. Dzięki temu są one traktowane jako „swego rodzaju system ekonomiczny wyższego rzędu, który funkcjonuje ponad gospodarką klasycznie pojmowaną" [Głowacki 2013: 444], ważne jest zatem nie tylko tworzenie wartości ekonomicznej przez wzrost zatrudnienia, produkcji czy PKB, ale stanowienie koordynatora i siły wzmacniającej dla nowych idei i nowych technologii, a poprzez to kształtowanie procesu zmiany. Dynamiczne podejście do kultury, nie jako zgromadzonego w przeszłości dorobku, ale jako elastyczności i adaptacji na 
potrzeby rozwoju zgromadzonej dotychczas wiedzy [Głowacki 2013: 444] stanowi nowe podejście wykorzystywane w inteligentnych specjalizacjach.

Na tej linii przecinają się zainteresowania badaczy kultury i przemysłów kreatywnych z teoriami i koncepcjami dotyczącymi inteligentnych specjalizacji. Wyznaczanie priorytetów badawczo-rozwojowych, technologicznych i innowacyjnych regionu lub kraju (w ramach inteligentnych specjalizacji) wpisuje się w koncepcję klastrów i przewag konkurencyjnych (pięciu sił) Michaela Portera, mówiącej o pozytywnym wpływie skupienia firm (sieci współpracy i współzawodnictwa) na danym obszarze na konkurencyjność globalną. Odpowiada również teorii biegunów wzrostu wskazującej koncentrację wzrostu gospodarczego w obszarach metropolitalnych François Perroux, a także bazie ekonomicznej, gdzie eksport stanowi główny czynnik wzrostu gospodarczego Homera Hoyta [Słodowa-Hełpa 2013: 90-91]. Zważywszy, że zarówno społeczeństwa, jak i gospodarka funkcjonują jak sieć [Manuel Castells], a wiedza i technologie stanowią największy zasób dla regionu [Richard Florida], specjalizacja pomagająca ograniczyć koszty, a zatem i zwiększyć konkurencyjność stanowi rozsądne i przetestowane rozwiązanie. Skoro idea specjalizacji regionalnej lub krajowej nie jest ideą nową, odpowiedzieć należy na pytanie, na czym polega przymiot tej specjalizacji jako „inteligentnej” (ang. smart).

\section{Inteligentne specjalizacje w Polsce i instrumenty ich realizacji}

Prace nad inteligentnymi specjalizacji rozpoczęto w Polsce od poziomu regionów. W latach 2001-2008 we wszystkich województwach trwały prace nad Regionalnymi Strategiami Innowacji (RSI), które były aktualizowane adekwatnie do wyników Narodowego Programu Foresight „Polska 2020”. To badanie obejmowało sektor nauki i w jego wyniku powstała koncepcja wsparcia działalności badawczo-rozwojowej dla instytucji naukowych - Krajowy Program Badań (2011). Równolegle w latach 2010-2012 na zlecenie Ministerstwa Gospodarki zidentyfikowano 99 technologii istotnych z punktu widzenia konkurencyjności i rozwoju przemysłu [Foresight technologiczny przemystu... 2012]. Na podstawie tych prac, wielu analiz krzyżowych i konsultacji społecznych powstał w 2014 roku program rozwoju przedsiębiorstw - Krajowe Inteligentne Specjalizacje. Powołano także organy niezbędne do zapewnienia funkcjonowania nowego systemu, w tym:

- Komitet Sterujący ds. KIS, który zarządza realizacją KIS, wybiera ekspertów do Grup Roboczych ds. KIS;

- Grupy robocze ds. KIS, które zajmują się opisem i uszczegóławianiem inteligentnych specjalizacji na potrzeby wniosków składanych do PO IR 2014-2020, prowadzą monitoring i tworzą rekomendacje systemowe; 
- Obserwatorium Gospodarcze, które analizuje bariery, szanse, rozwój sektora B+R+I, opracowuje raporty i ocenia wdrażanie KIS [Program Rozwoju Przedsiębiorstw... 2014].

Lista specjalizacji jest regularnie aktualizowana nie tylko w zakresie obszarów, ale także pod względem wymagań dotyczących finansowania projektów z Programu Operacyjnego Inteligentny Rozwój. Mianowicie w 2015 roku dodano dwie specjalizacje (technologie morskie i kreacyjne) do wcześniej istniejących 18 KIS. W tym samym roku, nastąpiło uruchomienie tak zwanych programów sektorowych przez Narodowe Centrum Badań i Rozwoju, w tym pierwszego programu w ramach PO IR „Szybka ścieżka”, który stanowi do dziś pod względem alokacji flagowe narzędzie NCBR dofinansowania prac $\mathrm{B}+\mathrm{R} w$ przedsiębiorstwach.

Aktualizacja Listy i Szczegółowego Opisu Krajowych Inteligentnych Specjalizacji przez Ministerstwo Przedsiębiorczości i Technologii dokonywana jest rokrocznie. W 2018 roku zmiana dotyczyła utworzenia specjalizacji „Gospodarka o obiegu zamkniętym - woda, surowce kopalne, odpady” (obejmująca 3 dotychczasowe specjalizacje: KIS 7-9) oraz drobnych modyfikacji opisu KIS 4 „Wysokosprawne, niskoemisyjne i zintegrowane układy wytwarzania, magazynowania, przesyłu i dystrybucji energii”. W 2019 roku połączono KIS „Sensory (w tym biosensory) i inteligentne sieci sensorowe” i KIS „Fotonika” w nową specjalizację „Elektronika i fotonika” oraz dokonano zmian opisów KIS 4 i KIS 7. Po uzyskaniu akceptacji Komitetu Sterującego ds. KIS zaktualizowana lista zaczęła obowiązywać od 1 stycznia 2020 roku i obecnie liczy czternaście pozycji.

Aktualne zestawienie obszarów tematycznych Krajowych Inteligentnych Specjalizacji prezentuje tabela 1 .

Tabela 1. Krajowe Inteligentne Specjalizacje (stan na 1 stycznia 2020 r.)

\begin{tabular}{|c|c|}
\hline \multicolumn{2}{|c|}{ Zdrowe społeczeństwo } \\
\hline KIS 1 & Zdrowe społeczeństwo \\
\hline \multicolumn{2}{|c|}{ Biogospodarka rolno-spożywcza, leśno-drzewna i środowiskowa } \\
\hline KIS 2 & $\begin{array}{l}\text { Innowacyjne technologie, procesy i produkty sektora rolno-spożywczego } \\
\text { i leśno-drzewnego }\end{array}$ \\
\hline KIS 3 & $\begin{array}{l}\text { Biotechnologiczne i chemiczne procesy, bioprodukty i produkty chemii spe- } \\
\text { cjalistycznej oraz inżynierii środowiska }\end{array}$ \\
\hline \multicolumn{2}{|c|}{ Zrównoważona energetyka } \\
\hline KIS 4 & $\begin{array}{l}\text { Wysokosprawne, niskoemisyjne i zintegrowane układy wytwarzania, magazy- } \\
\text { nowania, przesyłu i dystrybucji energii }\end{array}$ \\
\hline KIS 5 & Inteligentne i energooszczędne budownictwo \\
\hline KIS 6 & Rozwiązania transportowe przyjazne środowisku \\
\hline
\end{tabular}




\begin{tabular}{|l|l|}
\hline \multicolumn{2}{|l|}{ Gospodarka o obiegu zamkniętym - woda, surowce kopalne, odpady } \\
\hline KIS 7 & Gospodarka o obiegu zamkniętym - woda, surowce kopalne, odpady \\
\hline Innowacyjne technologie i procesy przemysłowe (w ujęciu horyzontalnym) \\
\hline KIS 8 & $\begin{array}{l}\text { Wielofunkcyjne materiały i kompozyty o zaawansowanych właściwościach, } \\
\text { w tym nanoprocesy i nanoprodukty }\end{array}$ \\
\hline KIS 9 & Elektronika i fotonika \\
\hline KIS 10 & $\begin{array}{l}\text { Inteligentne sieci i technologie informacyjno-komunikacyjne oraz geoinfor- } \\
\text { macyjne }\end{array}$ \\
\hline KIS 11 & Elektronika drukowana, organiczna i elastyczna \\
\hline KIS 12 & Automatyzacja i robotyka procesów technologicznych \\
\hline KIS 13 & Inteligentne technologie kreacyjne \\
\hline KIS 14 & $\begin{array}{l}\text { Innowacyjne technologie morskie w zakresie specjalistycznych jednostek } \\
\text { pływających, konstrukcji morskich i przybrzeżnych oraz logistyki opartej na } \\
\text { transporcie morskim i śródlądowym }\end{array}$ \\
\hline
\end{tabular}

Źródło: opracowanie własne na podstawie: https://smart.gov.pl/pl/aktualnosci/103-nowa-lista-krajowych-inteligentnych-specjalizacji-od-stycznia-2020-r [odczyt: 2.01.2020].

Z punktu widzenia rozwoju kultury na uwagę zasługuje KIS 13 „Inteligentne technologie kreacyjne", który obejmuje trzy działy. Są to:

- wzornictwo, w tym projektowanie wzornicze: produktów, usług, komunikacji i interfejsów, uwzględniające formę, funkcję, technologię, kreowanie potrzeb, tworzenie struktur informacyjnych i użytkowych, oraz projektowanie interakcji i doświadczenia użytkownika UX, a także narzędzia i metody wspierające wzorniczy proces projektowy;

- gry, obejmujące zarówno proces produkcji gier, jak i platformy, silniki i techniki przetwarzania, doskonalenie algorytmów i zastosowanie sztucznej inteligencji, nowe mechanizmy interakcji, cyfrową dystrybucję i wieloosobowe rozgrywki, narzędzia i wiedzę z zakresu procesu twórczego, a także zastosowanie gier w innych dziedzinach życia na przykład zdrowia czy edukacji;

- multimedia, w tym opracowanie metod i narzędzi wspomagających procesy wytwarzania i rozpowszechniania treści na przykład działania na podstawie oceny reakcji użytkowników, automatyzacja tworzenia czy współpraca i praca zespołowa w środowisku wirtualnym; kształtowanie rynku; wsparcie wytwarzania i rewitalizacji, dystrybucja i zarządzanie treściami oraz ich archiwizacja i inteligentny dostęp do treści.

Zakres wskazany w opisie KIS 13 nie odpowiada bezpośrednio polskim działom PKD zaliczanym do przemysłów kreatywnych, jednak beneficjentami wsparcia są bez wątpienia mieszczące w tej kategorii organizacje zarządzające kulturą w obszarze gier, multimediów czy wzornictwa. Podobnie cross-sektorowe ujęcie kultury występuje w regionalnych inteligentnych specjalizacjach. Dla przykładu w Małopolsce specjalizacja, która wykorzystuje potencjał kultury w tym regionie, została nazwana: 
„Przemysły kreatywne i czasu wolnego”. Obejmuje ona aktywności, które mają swoje źródło w indywidualnej kreacji, zdolnościach i talencie, mające potencjał tworzenia dobrobytu i miejsc pracy przez produkcję i eksploatację własności intelektualnej. Wyszczególniono w niej cztery dziedziny:

- przemysły kreatywne;

- projektowanie graficzne i wzornictwo przemysłowe (design);

- gry komputerowe i oprogramowanie (interactive leisure software);

- oraz przemysły czasu wolnego.

Przemysły kreatywne pojawiają się także w regionalnej specjalizacji województwa zachodniopomorskiego, gdzie wyznaczono RIS. „Usługi przyszłości (dynamicznie rozwijająca się branża ICT, IT, KPO czy przemysły kreatywne)". Warto też zaznaczyć, że odniesienie do przemysłów kreatywnych znajduje się w RIS-ach województw: łódzkiego, dolnośląskiego oraz śląskiego. Regiony te posiadają specjalizacje „Technologie informacyjno-komunikacyjne”, „Technologie komunikacyjne i informatyczne”, w które wpisują się multimedia i gry.

Podstawowymi instrumentami realizacji inteligentnych specjalizacji są programy operacyjne w ramach perspektywy finansowej 2014-2020. Chodzi tu przede wszystkim o Program Operacyjny Inteligentny Rozwój (PO IR), a także Program Operacyjny Polska Wschodnia (PO PW) i 16 regionalnych programów operacyjnych (RPO). Ważnym programem wspierających działalność badawczo-rozwojową w obszarze inteligentnych specjalizacji jest również Program Horyzont 2020.

Program Operacyjny Wiedza Edukacja Rozwój (POWER) tylko w kilku działaniach wzmacnia realizację inteligentnych specjalizacji. W wypadku Programu Operacyjnego Wiedza Edukacja Rozwój do kwestii KIS nawiązują opisy w następujących działaniach:

- Działania 2.2 „Wsparcie na rzecz zarządzania strategicznego przedsiębiorstw oraz budowy przewagi konkurencyjnej na rynku" - dla jednego z typów projektu możliwa jest:

realizacja przez partnerów społecznych działań mających na celu opracowanie analizy potrzeb rozwojowych MMSP (...), którzy nie posiadają planu lub strategii rozwoju, w tym m.in.: opracowanie analizy potrzeb rozwojowych MMSP lub też Identyfikacja potencjalnych odbiorców wsparcia lub przygotowanie propozycji planów rozwojowych określających zakres działań niezbędnych do zaspokojenia zidentyfikowanych potrzeb rozwojowych przedsiębiorstw oraz monitoring i doradztwo w zakresie ich wdrożenia (...) na poziomie grup przedsiębiorstw, np. branż, terytoriów, grup kooperujących w ramach łańcucha dostaw, klastrów lub w odniesieniu do inteligentnych specjalizacji [Szczegółowy Opis Osi Priorytetowych Programu Operacyjnego... 2018];

- Działania 2.12 „Zwiększenie wiedzy o potrzebach kwalifikacyjno-zawodowych" - w projektach realizowane działania obejmują: 
monitorowanie potrzeb przedsiębiorstw i pracowników w kontekście zapotrzebowania na kompetencje, w tym analiza struktury kompetencji na rynku pracy, w szczególności w zakresie potrzeb zgłaszanych przez sektorowe rady ds. kompetencji, a także analiza zapotrzebowania na kompetencje w branżach zaliczanych do grona inteligentnych specjalizacji [Szczegółowy Opis Osi Priorytetowych Programu Operacyjnego... 2018];

- Działania 3.1 „Kompetencje w szkolnictwie wyższym” rozwój oferty uczelni w zakresie realizacji trzeciej misji mogą obejmować:

tworzenie przez uczelnię innowacyjnych form aktywizacji społecznej i edukacyjnej mieszkańców regionu (w tym w szczególności kierowanych do osób wykluczonych społecznie), inicjowania przez uczelnię programów dokształcania dla osób w różnych grupach wiekowych zgodnych z lokalnymi i regionalnymi strategiami rozwoju, w szczególności z regionalnymi inteligentnymi specjalizacjami oraz wspierania uczelni w zakresie współpracy z lokalnymi organizacjami pozarządowymi [Szczegółowy Opis Osi Priorytetowych Programu Operacyjnego... 2018].

To nawiązanie stanowi o spójności wsparcia pomiędzy politykami: innowacyjną i rozwoju zasobów ludzkich (realizowaną przez POWER). Natomiast w Programie Operacyjnym Polska Cyfrowa brakuje w strategicznych dokumentach powiązania ze specjalizacjami, co ogranicza efekt synergii z polityką cyfryzacji.

PO IR to krajowy program współfinansowany ze środków Unii Europejskiej, drugi po Programie Infrastruktura i Środowisko dysponujący największą alokacją środków (prawie 9 mld euro). W ramach programu trzy na cztery osie priorytetowe (I, II i IV) ukierunkowane są wyłącznie na finansowanie działalności B+R mieszczącej się w krajowych inteligentnych specjalizacjach. W trzeciej osi premiowane są projekty wpisujące się w KIS-y. Alokacje środków w podziale na osie priorytetowe wskazano w tabeli 2.

Tabela 2. Alokacja przeznaczona na finansowanie KIS w PO IR 2014-2020

\begin{tabular}{|l|l|}
\hline Oś priorytetowa PO IR & Alokacja \\
\hline I oś - Wsparcie prowadzenia prac B+R przez przedsiębiorstwa & 3,85 mld euro \\
\hline $\begin{array}{l}\text { II oś - Wsparcie otoczenia i potencjału przedsiębiorstw do prowadzenia działalności } \\
\text { B+R+I }\end{array}$ & 1,04 mld euro \\
\hline III oś - Wsparcie innowacji w przedsiębiorstwach & 2,2 mld euro \\
\hline IV oś - Zwiększenie potencjału naukowo-badawczego & 1,22 mld euro \\
\hline
\end{tabular}

Źródło: opracowanie własne na podstawie: https://smart.gov.pl/pl/jakie-korzysci-daje-inteligentna-specjalizacja/ instrumenty-wsparcia-w-ramach-programow-operacyjnych [odczyt: 2.01.2020]. 


\section{og̣raniczenia w pozyskiwaniu wsparcia - wyniki badań}

Aplikowanie o środki europejskie nie jest procesem ani łatwym, ani szybkim. Choć obecnie odbywa się elektronicznie z wykorzystaniem generatorów wniosków, to sama procedura oceny projektu trwa do 90 dni. W ten okres nie jest wliczany czas związany z przygotowaniem wyjaśnień i stosownych uzupełnień na potrzeby oceny formalnej i merytorycznej projektu. Trzeba jeszcze dodać czas na przygotowanie projektu, zebranie dokumentacji, wypełnienie i złożenie formularza wniosku. Tym samym od pojawienia się koncepcji projektu do podpisania umowy o dofinansowanie zależnie od harmonogramu ogłaszania konkursów i składania wniosków upływa od sześciu miesięcy do nawet roku. Stanowi to istotną barierę wskazywaną przez beneficjentów, skutkującą dewaluacją wartości rynkowej planowego przedsięwzięcia, co potwierdzają wypowiedzi: „Chodzi o to, że czekało się strasznie długo na to. Człowiek coś wymyślił i czekał na decyzję tyle czasu, to już w między czasie założył firmę i często już to zrobił" [Raport z wywiadów fokusowych... 2016: 82].

Nierzadko o wiele łatwiej jest pozyskać prywatne środki od inwestorów niż dofinansowanie ze środków publicznych. Respondenci wskazywali także często na trudności związane z realizacją projektów współfinansowanych ze źródeł publicznych:

My chcieliśmy złożyć, bo mamy taki projekt innowacyjny, ale jak patrzyłem na te wszystkie punkty i tak dalej, bo trzeba się skontaktować i papiery, to stwierdziłem, że lepiej znaleźć inwestora niż tę dotację wziąć. I szybciej to zrobię, lepiej i sprawniej. Słyszałem po znajomych, którzy powiedzieli, że nie wzięliby dotacji, bo nie mogliby zrealizować projektu, realia się tak szybko zmieniają, że ten projekt musiałby być przebudowany, a oni nie mogli tego zrobić, musieli go utrzymywać przez jakiś czas, żeby dotacji nie stracić [Raport $z$ wywiadów fokusowych... 2016: 78-79].

Ponadto przedsiębiorcy najczęściej prowadzą działalność samofinansującą się i w ograniczonym zakresie interesują się pozyskiwaniem dofinansowania. Zatem w przeciwieństwie do organizacji pozarządowych, których działalność zależy od pozyskiwania środków zewnętrznych, są słabiej zmotywowani, i mniej zaznajomieni z pojawiającymi się szansami wsparcia dla ich działalności, w tym inteligentnymi specjalizacjami:

mało kto z nas o tym słyszał. To nie wróży dobrze, a jeżeli ktoś coś słyszał, to takich trochę sloganów. Wcale nie jest zdziwiony, że jednym z beneficjentów jest fundacja zajmująca się działalnością kulturalną, no ona jest bliżej, ona pracuje na obrzeżach tych różnych organów administracji państwowej, więc ma styczność, świadomość. Przeciętny przedsiębiorca o tym przeważnie nie wie [Raport z wywiadów fokusowych... 2016: 75, 84]. 
Dodatkowo same nazwy KIS niewiele mówią o zakresie specjalizacji i kategoryzacji działalności mieszczącej się w jej ramach. Brakuje bezpośredniego powiązania z Polską Klasyfikacją Działalności, co pozwoliło zweryfikować, czy dany podmiot mieści się w jej ramach. Sami przedsiębiorcy wskazywali, że przede wszystkim pojęcie przemysłu kreatywnego jest niejasne, nieostre, bardzo pojemne i można go różnie rozumieć:

przemysł kreatywny, pod to można podciągnąć wszystko, od wytwarzania szkliwek metodą cięcia laserowego przez konkretne nowe rozwiązania w przemyśle, do moderowania czy kontrolowania środowiska, bo to wszystko jest takie. Trudno mi tu dyskutować z kategoriami, które zostały wybrane. Czy to ma sens? Być może [Raport z wywiadów fokusowych... 2016: 76].

Interesującym wątkiem podejmowanym w wywiadach była współpraca przedsiębiorstw ze środowiskiem akademickim. Mówiono o braku motywacji do realizacji partnerskich projektów badawczo-rozwojowych w kooperacji z tym środowiskiem:

w większości przypadków uczelnia nie jest w stanie podołać temu projektowi, a poza tym nie jest zainteresowana finansowo. (...) Bo jeśli uczelnia by brała dofinansowanie do własnego projektu, to ta machina urzędnicza bardzo dobrze u nich to robi. Natomiast jeżeli oni są przymuszeni do tego, to uczelnia z tego specjalnie nic nie ma... W związku z tym taka współpraca się wtedy rozłazi zupełnie [Raport $z$ wywiadów fokusowych... 2016: 80].

Akcentowano również kwestie związane z systemem finansowania uczelni:

uczelnia nie jest tym zainteresowana, nie ma w tym interesu. Prędzej się znajdzie partnera w instytucie naukowo-badawczym, bo on żyje z projektów, ma takie zadania, ma wychodzone ścieżki, jak się granty zdobywa. Natomiast uczelnia ma inne źródła finansowania i realizacja projektu jest dla nich większym problemem niż korzyścią [Raport z wywiadów fokusowych... 2016: 80].

Powyższe opinie wskazują na niewystarczające kompetencje zasobów ludzkich, a także konieczność oraz skuteczność prowadzonych „szkoleń, w których koncentrowano się na wyjaśnianiu nieznanych przedsiębiorcom podstawowych zagadnień związanych z B+R" [Ocena wsparcia... 2018, cz. II: 6].

Ponadto firmy w niewystarczającym stopniu angażują własnych pracowników do tworzenia i prowadzenia procesów innowacyjnych, $w$ tym prac niezbędnych do aplikowania o wsparcie finansowe na działania B+R. Źródła takiego postępowania można upatrywać $\mathrm{w}$ wysokim poziomie efektu deadweight w sektorze kreatywnym, który wskazuje na możliwość realizacji działań bez udziału środków publicznych [Ocena wsparcia... 2018, cz. I: 50]. 
Wiele małych firm może mieć trudności w dopasowaniu się do kryteriów składania wniosków do programu, które stanowią pochodną modeli biznesowych i modeli produkcyjnych dużych firm. Dokumentacja konkursowa programu sektorowego Game Inn stanowi dla nich ograniczenie ze względu na krótki cykl życia produktu i niemożność zagwarantowania trwałości projektu [Ocena wsparcia... 2018, cz. I: 56].

Wyniki badań wskazują bariery związane z przygotowaniem projektu, aplikowaniem o jego wsparcie, a następnie realizacją. Jednocześnie dane ilościowe związane z liczbą złożonych wniosków o dofinansowanie świadczą, że na tle innych KIS $\mathrm{w}$ inteligentnych technologiach kreacyjnych składana jest duża liczba wniosków (1200 szt. do dnia 30 czerwca 2018 r.), co plasuje KIS w pierwszej połowie stawki najbardziej obleganych przez wnioskodawców specjalizacji (wykres 1).

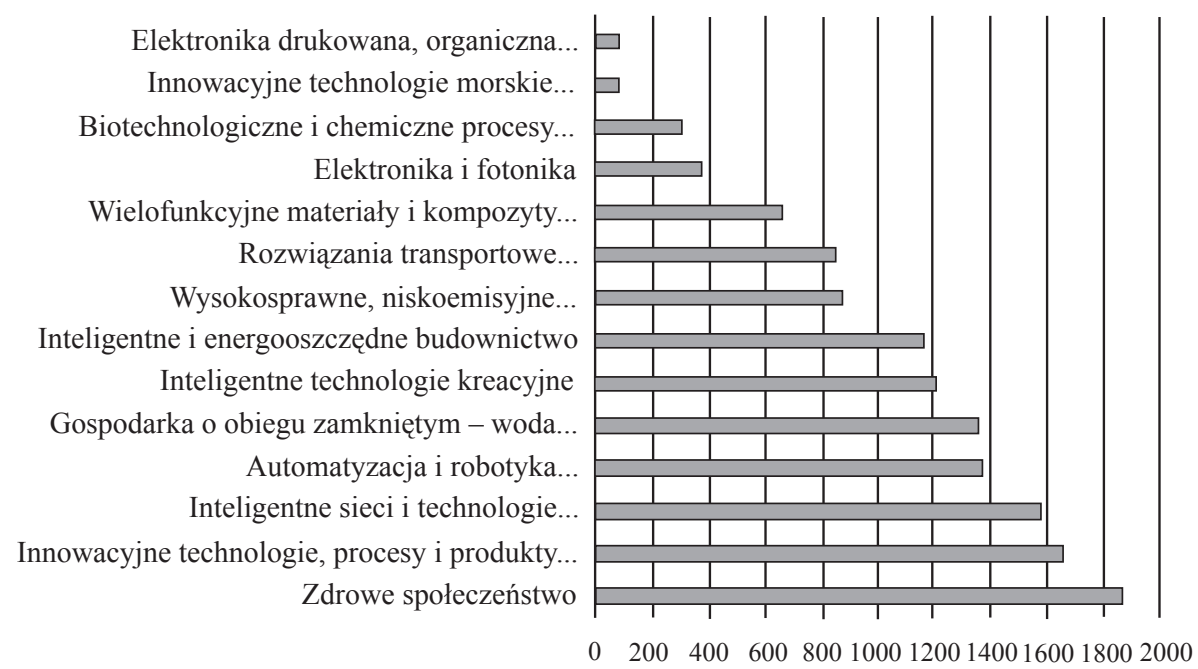

Wykres 1. Liczba wniosków przypadająca na poszczególne specjalizacje

Źródło: opracowanie własne na podstawie: Ewaluacja wsparcia w ramach PO IR... 2018: 35.

Jednocześnie obserwujemy tu najniższą średnią wartość dofinansowania projektu wynoszącą jedynie 2,4 mln zł (wykres 2). W porównaniu z KIS 7 Nowoczesne technologie pozyskiwania, przetwórstwa i wykorzystywania surowców naturalnych oraz wytwarzanie ich substytutów, gdzie średnia wartość wynosi $8 \mathrm{mln}$ zł, to aż $5,6 \mathrm{mln}$ różnicy. Wskazuje to także na słaby potencjał absorpcji środków w sektorze kultury ze względu na ograniczone możliwości inwestycyjne i zapewnienie wkładu własnego do projektów. 
Gospodarka o obiegu zamkniętym - woda... Zdrowe społeczeństwo Wielofunkcyjne materiały i kompozyty...

Rozwiązania transportowe... Automatyzacja i robotyka...

Biotechnologiczne i chemiczne procesy... Inteligentne i energooszczędne budownictwo Innowacyjne technologie, procesy i produkty...

Wysokosprawne, niskoemisyjne... Inteligentne sieci i technologie...

Elektronika i fotonika

Elektronika drukowana, organiczna i elastyczna Innowacyjne technologie morskie... Inteligentne technologie kreacyjne

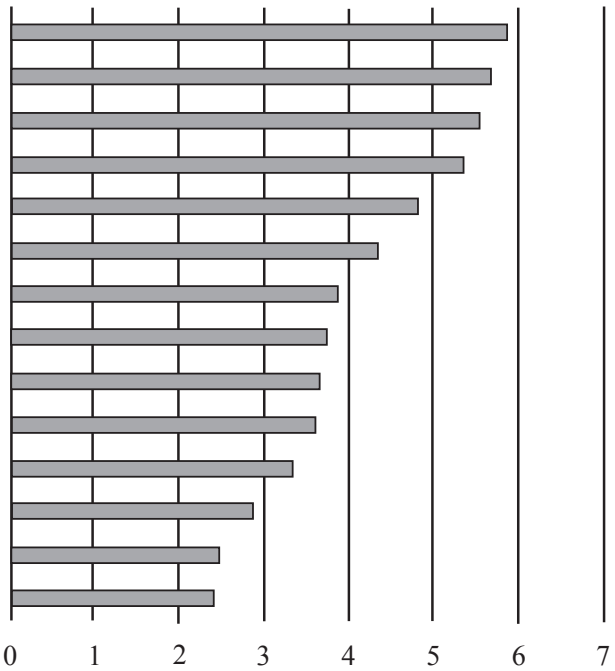

Wykres 2. Średnia wartość dofinansowania projektu w podziale na KIS [mln zł]

Źródło: opracowanie własne na podstawie: Ewaluacja wsparcia w ramach PO IR... 2018: 35.

Biotechnologiczne i chemiczne...

Elektronika i fotonika Rozwiązania transportowe... Wielofunkcyjne materiały i kompozyty...

Automatyzacja i robotyka procesów... Innowacyjne technologie, procesy i produkty...

Elektronika drukowana...

Innowacyjne technologie morskie..

Zdrowe społeczeństwo Inteligentne i energooszczędne budownictwo Wysokosprawne, niskoemisyjne.. Gospodarka o obiegu zamkniętym... Inteligentne technologie kreacyjne Inteligentne sieci i technologie...

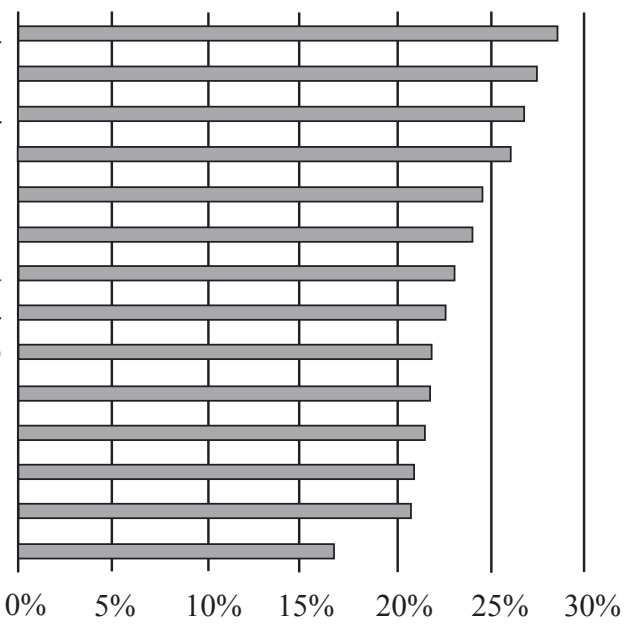

Wykres 3. Wskaźnik sukcesu w ubieganiu się o dofinansowanie projektu [\%]

Źródło: opracowanie własne na podstawie: Ewaluacja wsparcia w ramach PO IR... 2018: 35. 
Wskaźnik sukcesu (succes rate), informujący o procencie wnioskujących, którzy otrzymują dofinansowanie w zależności od KIS, oscyluje między $16,4 \%$ a 31,9\%. Dla inteligentnych technologii kreacyjnych wynosi $20,8 \%$, co oznacza, że średnio co piąty wniosek o dofinansowanie uzyskuje oczekiwane wsparcie przedsięwzięcia.

Analizę porównawczą wskaźnika sukcesu dla wszystkich KIS prezentuje wykres 3.

Prowadzenie prac badawczo-rozwojowych w kulturze - case study

Istotną barierą zarówno w planowaniu, jak i realizacji projektów B+R współfinansowanych w KIS okazuje się różnorodność nazewnictwa i wymagań instytucji wspierających odnośnie do specyfiki badań na różnych etapach projektu (zob. rycina 1).

Odpowiednie przyporządkowanie planowanych prac ma bardzo istotne znaczenie, gdyż od tego zależy między innymi procent dofinansowania projektu. Mianowicie mikro i małe przedsiębiorstwa standardowo otrzymać mogą:

- $70 \%$ - w wypadku badań przemysłowych, a w sytuacji, gdy planowane jest szerokie rozpowszechnianie wyników, intensywność wsparcia może wzrosnąć o premię $15 \%$ i maksymalnie do $80 \%$;

- $45 \%$ - w wypadku prac rozwojowych, a w sytuacji, gdy planowane jest szerokie rozpowszechnianie wyników, intensywność wsparcia może wzrosnąć o premię $15 \%$ i maksymalnie do $60 \%$.

$\mathrm{W}$ wypadku statusu średniego przedsiębiorstwa maksymalna pomoc (z premią za upowszechnianie wyników badań) wynosi 75\% w przypadku badań przemysłowych oraz 50\% w przypadku prac rozwojowych [Szczegółowy opis osi priorytetowych Programu Inteligentny Rozwój... 2020: 21].

Niestety odpowiedni opis i zakwalifikowanie prowadzonych badań stanowi istotne wyzwanie dla przedsiębiorców. Do analizy tego zagadnienia wykorzystana zostanie dokumentacja aplikacyjna projektu Roto 2.0 - innowacyjne obliczenia heterogeniczne CPU-GPU i stworzenie środowiska do budowy własnych bibliotek i ocena dokumentacji, które zostały udostępnione na potrzeby niniejszego artykułu przez start-up Flowbox sp. z o.o.

Flowbox działa w obszarze ICT i multimediów. Powstała w lipcu 2013 roku i w związku z zamknięciem studia filmowego w Alwerni stanowi kontynuację działalności filmowej w dziedzinie postprodukcji filmowej w Małopolsce. Od początku swojej działalności spółka była skupiona na tworzeniu własnych innowacyjnych technologii w dziedzinie oprogramowania komputerowego, które następnie zastosowano w autorskiej platformie Flowbox, służącej do tworzenia efektów specjalnych w branży audiowizualnej (film, gry wideo, reklama, telewizja, media internetowe). Głównym obszarem działania spółki Flowbox jest sprzedaż autorskiego produktu wspomagającego rotoskopię - aplikacji dostępnej pod adresem: https://flowbox.io/. Rotoskopia to podstawowy proces przy tworzeniu efektów specjalnych. Opierają się 

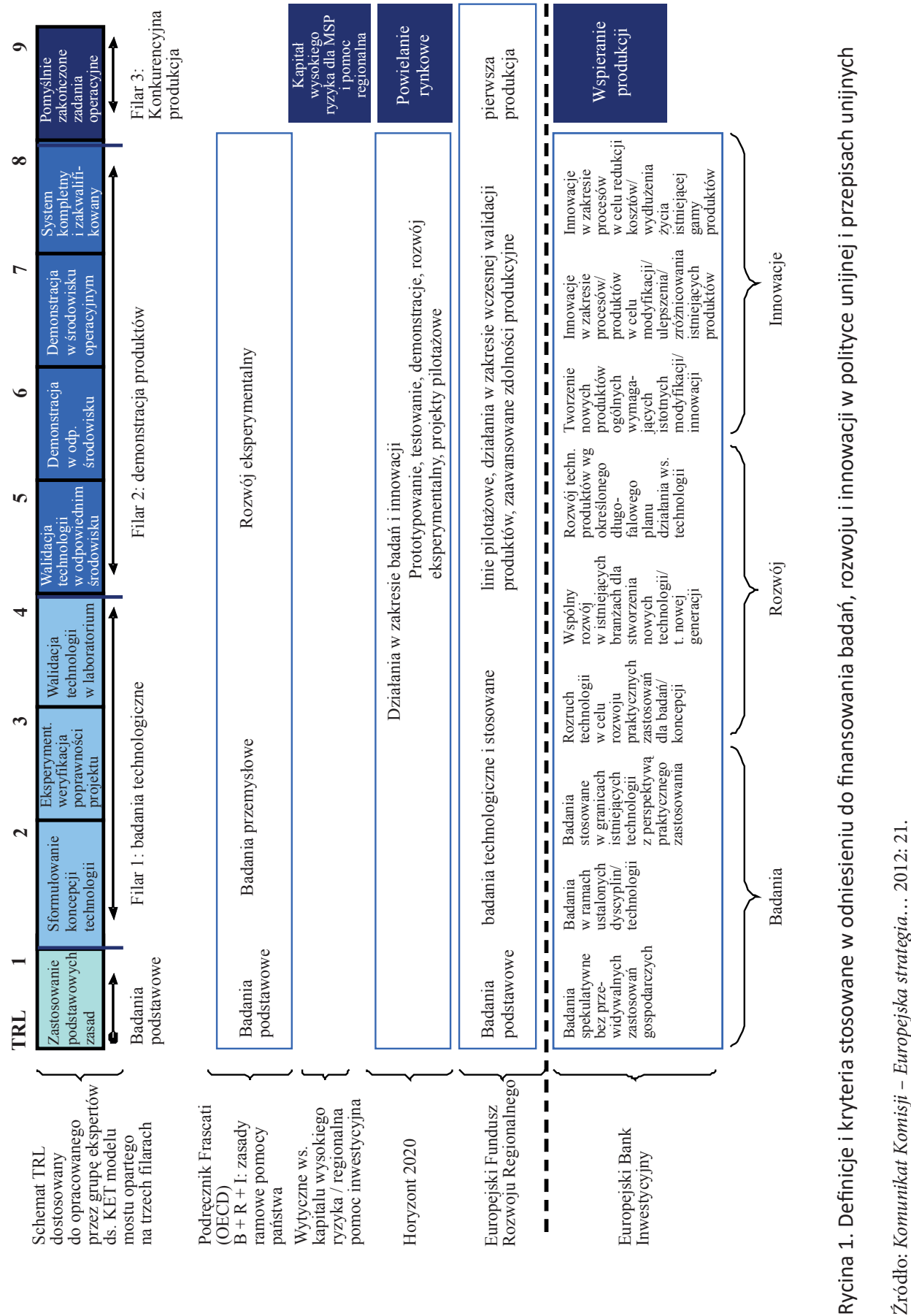
na niej kompozycja obrazu, korekcja koloru, restauracja (remastering) i tworzenie stereoskopii dla filmu, telewizji, reklamy i internetowych treści multimedialnych. Jednocześnie jest to proces bardzo żmudny i czasochłonny. Przy napiętych budżetach filmowych i reklamowych kluczową rzeczą jest wykonanie pracy szybciej i taniej.

Spółka Flowbox stworzyła platformę zorientowaną na pracę zespołową. Narzędzie pozwala na jednoczesną edycję materiału wideo oraz jego przeglądanie i ocenianie $\mathrm{z}$ zachowaniem możliwości pracy $\mathrm{w}$ czasie rzeczywistym $\mathrm{z}$ wielu urządzeń naraz. Aplikacja sprzedawana jest na rynku globalnym przez sklep online oraz kontakt bezpośredni. Klientami spółki są studia filmowe i reklamowe oraz artyści (freelancerzy) między innymi z Indii, Tajwanu, Korei Południowej, Singapuru, RPA, USA, Brazylii, Niemiec, Węgier, Rosji czy Polski, którzy subskrybują dostęp do nowoczesnej, szybkiej aplikacji desktopowej, działającej na Windows, Linux i Mac. Dostępne są licencje typu node based (przypisane do danego sprzętu) oraz licencje typu floating (umożliwiające korzystanie $\mathrm{z}$ aplikacji na wielu stacjach roboczych).

Spółka w 2017 roku aplikowała o dofinansowanie prac B+R rozwijających platformę ze środków na Projekty badawczo-rozwojowe przedsiębiorstw RPO MAŁOPOLSKA w ramach RIS Przemysły kreatywne i czasu wolnego. Celem projektu było przeprowadzenie prac pozwalających na optymalne wykonanie programu, minimalizujących czas oraz opracowanie narzędzi i bibliotek do wykorzystywania w innych projektach i/lub przez innych użytkowników. Oznaczałoby to stworzenie reużytkowalnych bibliotek wewnątrz aplikacji Flowbox z wykorzystaniem reprezentacji graficznej - tak zwanych nodów i połączeń z przepływem danych między nimi oraz dostarczenie narzędzi do ujęcia biblioteki w zamknięty moduł, który może być później wczytany na innym komputerze i tam użytkowany albo w postaci tak zwanej czarnej skrzynki, albo otwarty do dalszej modyfikacji przez użytkownika.

Doświadczenie i wiedza spółki w zakresie badań i rozwoju zdobyła już uznanie prywatnych inwestorów, którzy ją dokapitalizowali. Największym inwestorem w spółkę w kwocie ponad miliona złotych był Innovation Nest - wywodzący się z Krakowa fundusz venture capital sygnowany nazwiskiem Piotra Wilama, pioniera polskiego internetu i współtwórcy Onet.pl. Spółka korzystała także z preferencyjnego wsparcia z PARP w postaci pożyczki na rozwój aplikacji.

Niestety zarówno doświadczenie spółki, jak i wysoki poziom innowacyjności czy wpasowanie w obszar priorytetowy regionalnej specjalizacji nie zagwarantowały sukcesu w aplikowaniu o środki publiczne. Zgodnie z otrzymanymi przez wnioskodawce kartami oceny zadania planowane do realizacji w ramach projektu nie zostały prawidłowo przypisane do kategorii badań przemysłowych lub prac rozwojowych: „przypisanie zadań do typu prac $\mathrm{B}+\mathrm{R}$ jest niejednoznaczne, a zatem błędne" [Karta oceny merytorycznej wniosku o dofinansowanie projektu konkursowego RPMP.01.02.0112-0397/17: 3] i choć „projekt obejmuje opracowanie aplikacji (rozwój) według autorskiego pomysłu Wnioskodawcy i nie obejmuje czynności rutynowych związanych z oprogramowaniem w rozumieniu podręcznika Frascati” oraz „Projekt znajduje się 
co najmniej na TRL II, tj. określono koncepcję technologii i jej przyszłe zastosowanie", to nie został dopuszczony do kolejnego etapu oceny merytorycznej przed panelem ekspertów, co umożliwiłoby obronę koncepcji. Planowane do uzyskania wsparcie miało przyśpieszyć rozwój narzędzia z poziomu 1.2 do zakładanego poziomu 2.0. $\mathrm{Z}$ powodu ograniczonych środków na prace $\mathrm{B}+\mathrm{R}$ przedsięwzięcie to jest realizowane w ograniczonym zakresie. Niemniej jednak dzięki prywatnym inwestycjom platforma od momentu bezskutecznego aplikowania o środki z RIS osiągnęła poziom 1.7, co z jednej strony potwierdza znaczenie pozyskania dofinansowania jako istotny czynnik umożliwiający przyśpieszony rozwój przedsiębiorstw, z drugiej wskazuje na wysoki poziom efektu deadweight, potwierdzający, że finansowanie publiczne nie determinuje sukcesu i rozwoju przedsiębiorczości w obszarze przemysłów kreatywnych.

\section{Inteligentne specjalizacje w obszarze przemyslów kreatywnych - wnioski}

Pozyskiwanie środków publicznych na badania i rozwój w obszarze kultury regulowane jest takimi samymi wytycznymi jak w pozostałych KIS i nie uwzględnia specyfiki sektora i organizacji w nim działających. Należy zwrócić uwagę, że w przemysłach kreatywnych w Polsce dominują małe organizacje (ok. 97\% podmiotów sektora kreatywnego stanowią mikroprzedsiębiorstwa). „Przedsiębiorstwa te $\mathrm{w}$ większości oparte są na prototypach lub projekcie, w ogromnym stopniu uzależnione są od flagowego produktu lub usługi i w znacznej mierze zależą od indywidualnego talentu i podejmowanego ryzyka" [Obłąkowska-Kubiak 2014: 39]. Podmioty charakteryzowane jako duże, tj. zatrudniające powyżej 250 pracowników, stanowią kilka promili oraz pod względem lokalizacyjnym działają tylko w największych miastach.

Ponadto regiony w UE i w Polsce są zróżnicowane pod względem poziomu rozwoju społeczno-gospodarczego. Dlatego, choć intencją krajowych inteligentnych specjalizacji jest gospodarczy rozwój Polski, to w wypadku przemysłów kreatywnych premiuje on największe organizacje posiadające możliwości wynajęcia specjalistycznych agencji doradczych, bardzo często zlokalizowane w centralnym regionie kraju. Innowacyjność w przemysłach kreatywnych nie wymaga przemysłowego zaplecza czy bogatych laboratoriów, jak w wypadku innych specjalizacji. Świadczy o tym między innymi najniższe średnie dofinansowanie otrzymywane przez firmy w ramach KIS 13. Niemniej wymagania dotyczące aplikowania o środki z PO IR są takie same bez względu na sektor. W konsekwencji zdarza się, że premiowane są organizacje, które posiadały zasoby na przygotowanie specjalistycznej dokumentacji i mogły spełnić kryteria konkursu między innymi dotyczące zapewnienia trwałości projektu. Są przypadki, że niektóre z nich otrzymują dofinansowanie przez kilka kolejnych lat [The Farm 51 wśród zwycięzców... 2019: 51]. 
Przemysły kreatywne, chociaż mogłyby się stać niewymagającym istotnych inwestycji obszarem gospodarki dla peryferyjnych obszarów, tworząc klastry czy lokalne partnerstwa i pobudzając wykorzystanie unikatowych przewag i udogodnień, takich jak rekreacja, festiwale, muzyka, turystyka, kulinaria, to z punktu widzenia wymagań stawianych projektom badawczo-rozwojowym mają bardzo ograniczony potencjał (zasoby kapitału i know-how) do pozyskiwania istotnych funduszy z inteligentnych specjalizacji. Tym bardziej że brakuje pozytywnych efektów zewnętrznych (spill-overs) generowanych przez instytucje badawczo-rozwojowe (np. uniwersytety) w tym obszarze.

Dużą niewiadomą są skutki, jakie przyniesie wdrożenie specjalizacji. Z jednej strony obserwuje się pogłębianie różnic między dużymi graczami (beneficjentami systemu) a małymi organizacjami, które nie potrafią sięgnąć po oferowane wsparcie. Obawiając się negatywnych konsekwencji słabej penetracji środków na badania i rozwój, a przez to zwiększającej się dysproporcji między większymi i mniejszymi firmami, Ministerstwo Inwestycji i Rozwoju przygotowało narzędzie wsparcia dla przedsiębiorców dotychczas nieaplikujących o środki europejskie - Sprawdzimy Twój Eksperymentalny Pomysł na Projekt (STEP) składający się z dwóch ścieżek: I ścieżka - Wstępna Weryfikacja Pomysłu na Projekt oraz II ścieżka - Innovation Coach. Obydwie ścieżki mają pomóc małym innowacyjnym firmom w przezwyciężeniu ograniczeń zdiagnozowanych w niniejszym artykule i umożliwić otrzymanie wsparcia, a przez to wzmocnić realizację inteligentnych specjalizacji.

\section{Zakończenie}

Wybór inteligentnych specjalizacji to nieuchronnie wybór zwycięzców i przegranych w walce o unijne fundusze. Dużym sukcesem jest to, że kultura została zauważona jako obszar innowacji i budowania gospodarki opartej na wiedzy. Jednak implementacja inteligentnych specjalizacji nie jest dostępna dla szerokiego grona przedsiębiorców. Firmy nie wiedzą o tego rodzaju wsparciu, mają ograniczone możliwości przygotowania trudnej dokumentacji zarówno z powodu długotrwałego procesu, jak i skomplikowanej terminologii służącej opisowi ich działań.

Ponadto warunki aplikowania nie uwzględniają unikatowej specyfiki poszczególnych sektorów, a ze względu na biurokratyczny charakter i uwarunkowania wydatkowania środków publicznych inwestują w projekty badawczo-rozwojowe obarczone najmniejszym ryzykiem. Podczas gdy projekty o większym ryzyku to te, które wychodzą naprzeciw przyszłym, nieprzewidzianym i istotnym przemianom w gospodarce, nauce, technice, polityce, prawie, społeczeństwie. Rewolucja cyfrowa (digital disruption), dzikie karty (wildcards), zwane też czarnymi łabędziami (blackswans), mogą w fundamentalny sposób zmienić i gospodarkę, i uwarunkowania poszczególnych branż, co sprawi, że przyjęte rozwiązania okażą się nieefektywne. 
Promując mocnych graczy, których prace badawczo-rozwojowe są poprawne i bezpieczne, można nie dostrzec projektów przełomowych i stracić szansę aktywnego uczestnictwa w przełomowych zmianach gospodarki.

\section{Bibliografia}

Ewaluacja wsparcia $w$ ramach PO IR $w$ zakresie Krajowych Inteligentnych Specjalizacji, Warszawa, $24.10 .2018 \mathrm{r}$.

The Farm 51 wśród zwycięzców konkursu GameINN!, 1.10.2019, http://www.thefarm51.com/ the-farm-51-wsrod-zwyciezcow-tegorocznego-konkursu-gameinn/ [odczyt: 2.01.2020].

Florida R. (2010), Narodziny klasy kreatywnej oraz jej wpływ na przeobrażenia w charakterze pracy, wypoczynku, społeczeństwa i życia codziennego, tłum. T. Krzyżanowski, M. Penkala, Warszawa: Narodowe Centrum Kultury.

Foray D., Goddard J., Goenaga Beldarrain X. et al. (2012), Guide to Research and Innovation Strategies for Smart Specialisations (RIS 3), Luxembourg: Publications Office of the European Union, https://ec.europa.eu/regional_policy/sources/docgener/presenta/smart_specialisation/smart_ris3_2012.pdf [odczyt: 1.01.2020].

Foresight technologiczny przemyslu - InSight2030: aktualizacja wyników oraz krajowa strategia inteligentnej specjalizacji (smart specialization) (2012), J. Gorzoch (red.), Warszawa: Ministerstwo Gospodarki.

Głowacki J. (2013), Przemysty kreatywne i ich wptyw na gospodarkę, [w:] J. Hausner, A. Karwińska, J. Purchla (red.), Kultura a rozwój, Warszawa: Narodowe Centrum Kultury, http:// nck.pl/media/2014-01-21/podrecznik_copyl.pdf [odczyt: 2.01.2020].

Główny Urząd Statystyczny (GUS) (2016), Finanse kultury w latach 2007-2015.

https://smart.gov.pl/pl/jakie-korzysci-daje-inteligentna-specjalizacja/instrumenty-wsparcia-w-ramach-programow-operacyjnych [odczyt: 2.01.2020].

Ilczuk D. (2012), Ekonomika kultury, Warszawa: Wydawnictwo Naukowe PWN.

Ilczuk D., Krzysztofek K. (2011), Znaczenie Kompetencji Kulturowych dla Budowania Kreatywności i Kapitału Intelektualnego Europy, Ekspertyza na zlecenie Ministerstwa Kultury i Dziedzictwa Narodowego, wersja 1.0, Fundacja Pro Cultura w Warszawie, Warszawa, https://www.nck.pl/upload/attachments/302457/znaczenie_kompetencji_kulturowych_ dla_budowania_kreatywnosci_i_kapitau_intelektualnego_europy.pdf [odczyt: 3.01.2020]. Jakościowe badanie małopolskich przedsiębiorstw działających $w$ obrębie inteligentnych specjalizacji regionu (2016), Kraków, https://www.malopolska.pl/publikacje/gospodarka/ jakosciowe-badanie-malopolskich-przedsiebiorstw-dzialajacych-w-obrebie-inteligentnych-specjalizacji [odczyt: 3.01.2020].

Karta oceny merytorycznej wniosku o dofinansowanie projektu konkursowego RPMP.01.02.01$-12-0397 / 17$. 
Kasprzak R. (2017), Creative Industries in the Polish Economy: Growth and Operating Conditions, [w:] C. Chapain, T. Stryjakiewicz, Creative Industries in Europe, Cham: Springer International Publishing, s. 151-176.

KE (2012), Komunikat Komisji do Parlamentu i Rady w sprawie europejskiego partnerstwa innowacyjnego na rzecz wydajnego i zrównoważonego rozwoju z dnia 29 lutego 2012, COM 79, wersja ostateczna, Bruksela: Komisja Europejska EUR-Lex.

KEA (2006), The Economy of Culture in Europe KEA European Affairs, http://www.keanet.eu/ ecoculture/studynew.pdf [odczyt: 2.01.2020].

Knaś P. (2012), Sektor kultury. Ujęcie instytucjonalne i znaczenie gospodarcze. Samorząd Województwa Małopolskiego, http://badania-w-kulturze.mik.krakow.pl/2012/02/22/sektor-kultury-ujecie-instytucjonalne-i-znaczenie-gospodarcze [odczyt: 2.01.2020].

Komunikat Komisji - Europejska strategia w dziedzinie kluczowych technologii wspomagających droga do wzrostu i miejsc pracy, COM/2012/0341 final (2012), https://eur-lex.europa.eu/ legal-content/pl/ALL/?uri=CELEX\%3A52012DC0341 [odczyt: 2.01.2020].

Kopeć K. (2014), Finansowanie kultury w ramach społecznej odpowiedzialności biznesu, Kraków: Libron.

Krajowe inteligentne specjalizacje. Wersja 6, Warszawa: Ministerstwo Rozwoju. https://smart. gov.pl/images/Opisy-KIS_-werja-6_FINAL_01.01.2020.pdf [odczyt: 2.01.2020].

Krajowy Program Badań (2011), Uchwała Rady Ministrów z dnia 16 sierpnia 2011 r. w sprawie ustanowienia Krajowego Programu Badań, http://www.bip.nauka.gov.pl/krajowy-program-badan/ [odczyt: 2.01.2020].

Landry Ch. (2008), The Creative City: A Toolkit for Urban Innovators, London: Routledge.

Materska-Samek M. (2008), Europejski kontekst finansowania cyfryzacji kin, „Zarządzanie w Kulturze", t. 9, s. 107-114.

Materska-Samek M. (2010), Europejskie wzorce cyfryzacji. Małopolska Sieć Kin Cyfrowych, „Bliżej Brukseli”, nr 5: Przemyst kreatywny.

Nazarko Ł. (2014), Inteligentne specjalizacje polskich regionów - przyczynek do ewaluacji, „Przedsiębiorczość i Zarządzanie”, t. 15, z. 8, http://piz.san.edu.pl/docs/e-XV-8-1.pdf [odczyt: 2.01.2020].

Nowa lista krajowych inteligentnych specjalizacji od stycznia 2020 r. https://smart.gov.pl/pl/ aktualnosci/103-nowa-lista-krajowych-inteligentnych-specjalizacji-od-stycznia-2020-r [odczyt: 2.01.2020].

Obłąkowska-Kubiak K. (2014), Sektor kultury i kreatywny jako wyzwanie dla małych i średnich przedsiębiorstw w Polsce, „Studia Ekonomiczne Regionu Łódzkiego”, nr 13.

Ocena wsparcia udzielonego w ramach działania 1.2 PO IR na rozwój wybranych sektorów gospodarki (2018).

OECD (2018), Podręcznik Frascati 2015: Zalecenia dotyczące pozyskiwania i prezentowania danych z zakresu działalności badawczej i rozwojowej. Pomiar działalności naukowo-technicznej i innowacyjnej, Warszawa-Paris: GUS, OECD Publishing, https://doi. org/10.1787/9788388718977-pl [odczyt: 2.01.2020]. 
Pięta-Kanurska M. (2013), Wpływ sektora kreatywnego na kształtowanie się polskich metropolii, Monografie i Opracowania Uniwersytetu Ekonomicznego we Wrocławiu, Wrocław: Wydawnictwo Uniwersytetu Ekonomicznego.

Program Rozwoju Przedsiębiorstw do 2020 r. (2014), Ministerstwo Gospodarki, 8.04.2014.

Prusik M., Banaszek A., Źróbek R. (2015), Rola funduszy europejskich w finansowaniu procesu rewitalizacji miast w Polsce, „Studia Miejskie”, nr 17, s. 49-61, http://cejsh.icm.edu.pl/ cejsh/element/bwmeta1.element.desklight-20fe3353-9b4f-480f-a0ed-934518a8f16a [odczyt: 2.01.2020].

Raport $z$ wywiadów fokusowych $z$ przedstawicielami przedsiębiorców działających $w$ ramach inteligentnych specjalizacji województwa małopolskiego (2016), ASM - Centrum Badań i Analiz Rynku.

Rozporządzenie Parlamentu Europejskiego i Rady (UE), nr 1303/2013 z 17.12.2013 ustanawiające wspólne przepisy dotyczące EFRR, EFS, FS, EFRROW oraz EFMiR (2013), https://www. funduszeeuropejskie.gov.pl/strony/o-funduszach/dokumenty/rozporzadzenie-parlamentu-europejskiego-i-rady-ue-nr-13032013-z-dnia-17-grudnia-2013-roku-ustanawiajace-wspolne-przepisy-dotyczace-efrr-efs-fs-effrow-oraz-efmir/ [odczyt: 2.01.2020].

Słodowa-Hełpa M. (2013), Inteligentna specjalizacja polskich regionów. Warunki, wyzwania i dylematy, „Roczniki Nauk Społecznych”, nr 5 (41), 1, s. 87-120.

Smoleń M. (2003), Przemysty kultury. Wpływ na rozwój miast, Kraków: Wydawnictwo Uniwersytetu Jagiellońskiego.

Sprawdzimy Twój Eksperymentalny Pomysł (STEP), http://www.poir.gov.pl/strony/o-programie/ sprawdzimy-twoj-eksperymentalny-pomysl-step [odczyt: 2.01.2020].

Szczegółowy opis osi priorytetowych Programu Inteligentny Rozwój 2014-2020, Warszawa, luty 2020, https://www.poir.gov.pl/media/85612/aktualizacja_SZOOP_luty_2020.pdf [odczyt: 2.01.2020].

Szczegółowy Opis Osi Priorytetowych Programu Operacyjnego Wiedza Edukacja Rozwój 20142020, Wersja 12, Warszawa, 3.08.2018 r.

Throsby D. (2010), Ekonomia i kultura, tłum. O. Siara, Warszawa: Narodowe Centrum Kultury.

Ulatowska R., Grawon A., Klimas-Kuchta E., Małkiewicz E., Materska-Samek M., Potoczny J. (red.) (2012), Innowacje i nowe technologie przemysłów kreatywnych: perspektywy rozwoju rynku Audiowizualnego w Małopolsce, Kraków: Fundacja Rozwoju Kina, http://www.pi.gov. pl/PARPFiles/file/INNOWACYJNA_FIRMA/20130307_Raport_kreat_malopolski.pdf [odczyt: 2.01.2020].

Znaczenie gospodarcze sektora kultury w Polsce w latach 2008-2015 (2017), Warszawa: Instytut Badań Strukturalnych. 